\title{
Transplant Inequalities - A United Kingdom Perspective
}

\author{
Gurch Randhawa \\ Institute for Health Research, University of Bedfordshire,
}

UK

\section{Introduction}

The UK's Organ Donation Taskforce brought policy and resource focus to tackling transplant-related inequalities. In its first report, they stated, 'There is an urgent requirement to identify and implement the most effective methods through which organ donation and the "gift of life" can be promoted to the general public, and specifically to the BME (Black and minority ethnic) population. Research should be commissioned through Department of Health Research and Development funding' (Department of Health 2008a). The Taskforce's second report stated that 'The Taskforce strongly recommends that the Programme Delivery Board builds on the foundations of the interviews with faith and belief groups...., to ensure that the valuable dialogue that was established is maintained' (Department of Health 2008b).

These recommendations were in response to the plethora of evidence that highlights the variation in - demand for, access to, and waiting times for - transplant services in the UK. These variations impact upon minority ethnic communities in particular. The solutions to rectifying this situation are complex and require a holistic approach that considers both the short-term requirement to increase the number of organ donors from minority ethnic groups, and the longer term focus to decrease the number of minority ethnic patients requiring a transplant, via preventative strategies.

\section{Background}

South Asians (those originating from the Indian subcontinent - India, Sri Lanka, Pakistan and Bangladesh) and African-Caribbean communities have a high prevalence of Type 2 diabetes (Riste et al., 2001; Forouhi et al., 2006; Roderick et al., 2011). A further complication is that diabetic nephropathy is the major cause of end-stage renal failure (ESRF) in South Asian and African-Caribbean patients receiving renal replacement therapy (RRT), either by dialysis or transplantation (Roderick et al., 2011). Furthermore, South Asians with diabetes are at much greater risk of developing ESRF compared to 'White' Caucasians (Riste et al., 2001; Forouhi et al., 2006; Roderick et al., 1996). Thus, not only are South Asians and AfricanCaribbeans more prone to diabetes than Whites, they are more likely to develop ESRF as a consequence. 
Importantly, the South Asian and African-Caribbean populations in the UK are relatively young compared to the White population. Since the prevalence of ESRF increases with age, this has major implications for the future need for RRT and highlights the urgent need for preventive measures (Randhawa 1998). The incidence of ESRF has significant consequences for both local and national NHS resources.

Kidney transplantation is the preferred mode of RRT for eligible patients with end-stage renal failure. There are currently approximately 8,000 people on the transplant waiting list in the UK - the majority waiting for kidney transplants, but substantial numbers also waiting for heart, lung, and liver transplants. However, a closer examination of the national waiting list reveals that some minority ethnic groups are greater represented than others. For example:

- 1 in 5 people waiting for a transplant are from the African-Caribbean or South Asian communities (Table 1).

\begin{tabular}{|c|c|c|c|c|c|c|c|c|c|c|c|c|c|c|c|c|c|}
\hline \multirow{3}{*}{ Ethnicity } & \multicolumn{15}{|c|}{ Organ awaited } & \multirow{2}{*}{\multicolumn{2}{|c|}{ Total }} \\
\hline & \multicolumn{2}{|c|}{ Kidney } & \multicolumn{2}{|c|}{ Pancreas } & \multicolumn{2}{|c|}{$\mathbf{K} \& \mathbf{P}$} & \multicolumn{2}{|c|}{ Heart } & \multicolumn{2}{|c|}{ Lung } & \multicolumn{2}{|c|}{ Heart/ lung } & \multicolumn{2}{|c|}{ Liver } & \multirow{2}{*}{\begin{tabular}{|c} 
Multi-organ \\
N
\end{tabular}} & & \\
\hline & $\mathbf{N}$ & $\%$ & $\mathbf{N}$ & $\%$ & $\mathbf{N}$ & $\%$ & $\mathbf{N}$ & $\%$ & $\mathbf{N}$ & $\%$ & $\mathbf{N}$ & $\%$ & & $\%$ & & $N$ & $\%$ \\
\hline White & 6802 & 74.7 & 77 & 92.8 & 346 & 93.3 & 90 & 90.9 & 222 & 96.1 & 10 & 83.3 & 27 & 82.7 & 24 & 7848 & 76.5 \\
\hline Asian & 1360 & 14.9 & 2 & 2.4 & 18 & 4.9 & 5 & 5.1 & 2 & 0.9 & 2 & 16.7 & 37 & 11 & 0 & 1426 & 13.9 \\
\hline Black & 700 & 7.7 & 2 & 2.4 & 3 & 0.8 & 1 & 1 & 5 & 2.2 & 0 & 0 & & 1.8 & 0 & 717 & 7.0 \\
\hline Chinese & 97 & 1.1 & 0 & 0 & 1 & 0.3 & 1 & 1 & 0 & 0 & 0 & 0 & & 0.6 & 0 & 101 & 1.0 \\
\hline Mixed & 19 & 0.2 & 0 & 0 & 0 & 0 & 0 & 0 & 0 & 0 & 0 & 0 & 0 & 0 & 0 & 19 & 0.2 \\
\hline Other & 125 & 1.4 & 2 & 2.4 & 3 & 0.8 & 2 & 2 & 2 & 0.9 & 0 & 0 & & 3.3 & 0 & 145 & 1.4 \\
\hline Not rec. & 6 & 0.1 & 0 & 0 & 0 & 0 & 0 & 0 & 0 & 0 & 0 & 0 & & 0.6 & 0 & 8 & 0.1 \\
\hline Total & 9109 & & 83 & & 371 & & 99 & & 231 & & 12 & & 33 & & 24 & 10264 & \\
\hline
\end{tabular}

Source: NHS Blood \& Transplant, 2009

Table 1. Patients listed (active or suspended) for an organ transplant in the UK as at $31^{\text {st }}$ December 2008, by ethnic origin and organ

- $14 \%$ of people waiting for a kidney transplant are South Asian and over $7 \%$ are AfricanCaribbean (Table 2), even though they compromise only $4 \%$ and $2 \%$ respectively of the general population. 


\begin{tabular}{|c|c|c|c|c|c|c|c|c|}
\hline \multirow{2}{*}{$\begin{array}{l}\text { Age } \\
\text { (yrs) }\end{array}$} & \multicolumn{7}{|c|}{ Ethnic origin } & \multirow{2}{*}{ Total } \\
\hline & White & Asian & Black & Chinese & Mixed & Other & Not rec. & \\
\hline $0-9$ & $0.5 \%$ & $0.9 \%$ & $0.4 \%$ & $0.0 \%$ & $5.3 \%$ & $0.0 \%$ & $0.0 \%$ & $0.6 \%$ \\
\hline $10-19$ & $1.2 \%$ & $2.3 \%$ & $1.4 \%$ & $1.0 \%$ & $5.3 \%$ & $0.0 \%$ & $0.0 \%$ & $1.4 \%$ \\
\hline $20-29$ & $6.2 \%$ & $7.4 \%$ & $4.4 \%$ & $4.1 \%$ & 10.5 & $7.8 \%$ & $0.0 \%$ & $6.3 \%$ \\
\hline $30-39$ & $11.7 \%$ & $13.1 \%$ & $16.6 \%$ & $9.2 \%$ & $21.1 \%$ & $18.0 \%$ & $16.7 \%$ & $12.3 \%$ \\
\hline $40-49$ & $22.7 \%$ & $20.8 \%$ & $34.3 \%$ & $17.4 \%$ & $21.1 \%$ & $28.1 \%$ & $66.7 \%$ & $23.3 \%$ \\
\hline $50-59$ & $25.0 \%$ & $31.1 \%$ & $23.0 \%$ & $40.8 \%$ & $21.1 \%$ & $25.0 \%$ & $0.0 \%$ & $25.9 \%$ \\
\hline $60-69$ & $24.6 \%$ & $19.4 \%$ & $15.7 \%$ & $21.4 \%$ & $10.5 \%$ & $15.6 \%$ & $16.7 \%$ & $23.0 \%$ \\
\hline $70-79$ & $7.9 \%$ & $4.9 \%$ & $4.0 \%$ & $6.1 \%$ & $5.3 \%$ & $5.5 \%$ & $0.0 \%$ & $7.1 \%$ \\
\hline $80+$ & $0.1 \%$ & $0.1 \%$ & $0.1 \%$ & $0.0 \%$ & $0.0 \%$ & $0.0 \%$ & $0.0 \%$ & $0.1 \%$ \\
\hline Total & 7166 & 1378 & 703 & 98 & 19 & 128 & 6 & 9498 \\
\hline Total \% & $75.5 \%$ & $14.5 \%$ & $7.4 \%$ & $1.0 \%$ & $0.2 \%$ & $1.4 \%$ & $0.0 \%$ & \\
\hline Pop \% & $92.1 \%$ & $4.0 \%$ & $2.0 \%$ & $0.4 \%$ & $1.1 \%$ & $0.4 \%$ & & \\
\hline
\end{tabular}

Source: NHS Blood \& Transplant, 2009

Table 2. \% registered (inc suspended) on list for a kidney (inc. kidney/pancreas) transplant in UK as at 31 December 2008, by age decade and ethnic origin

- $\quad$ South Asian people are also more likely to need a liver transplant. While $4 \%$ of the UK population are South Asian, Asian people comprise over 10\% of the liver transplant list (Table 3). This is because viral hepatitis - hepatitis B \& C - that can lead to liver damage and liver failure is more prevalent in the South Asian population.

\begin{tabular}{|c|c|c|c|c|c|c|c|}
\hline \multirow{2}{*}{$\begin{array}{l}\text { Age } \\
\text { (yrs) }\end{array}$} & \multicolumn{6}{|c|}{ Ethnic origin } & \multirow{2}{*}{ Total } \\
\hline & White & Asian & Black & Chinese & Mixed & Other & \\
\hline $0-9$ & 14 & 1 & 0 & 0 & 0 & 0 & 15 \\
\hline $10-19$ & 8 & 1 & 0 & 0 & 0 & 1 & 10 \\
\hline $20-29$ & 15 & 3 & 1 & 0 & 0 & 3 & 22 \\
\hline $30-39$ & 21 & 1 & 1 & 0 & 0 & 1 & 24 \\
\hline $40-49$ & 55 & 11 & 0 & 0 & 0 & 2 & 68 \\
\hline $50-59$ & 109 & 16 & 4 & 0 & 0 & 2 & 131 \\
\hline $60-69$ & 75 & 4 & 0 & 2 & 0 & 3 & 84 \\
\hline $70-79$ & 1 & 0 & 0 & 0 & 0 & 1 & 2 \\
\hline Total & 298 & 37 & 6 & 2 & 0 & 13 & 356 \\
\hline $\begin{array}{c}\text { Total } \\
\%\end{array}$ & $83.7 \%$ & $10.4 \%$ & $1.7 \%$ & $0.6 \%$ & $0.0 \%$ & $3.7 \%$ & \\
\hline Pop \% & $92.1 \%$ & $4.0 \%$ & $2.0 \%$ & $0.4 \%$ & $1.1 \%$ & $0.4 \%$ & \\
\hline
\end{tabular}

Source: NHS Blood \& Transplant, 2009

Table 3. Number registered on list for a liver transplant in UK as at 31 December 2008, by age decade and ethnic origin 
- Just $1 \%$ of people registered on the Organ Donor Register are South Asian and $0.3 \%$ of people registered are African-Caribbean

- $1.2 \%$ of people who donate kidneys after their death are South Asian and $0.7 \%$ are African-Caribbean (Table 4).

\begin{tabular}{|c|c|c|c|c|c|c|c|}
\hline \multirow{2}{*}{ Donor type } & \multicolumn{6}{|c|}{ Ethnic origin } & \multirow{2}{*}{ Total } \\
\cline { 2 - 7 } & White & Asian & Black & Chinese & Mixed & Other & \\
\hline Deceased & 2135 & 33 & 19 & 4 & 11 & 5 & 2207 \\
\hline$\%$ & $96.7 \%$ & $1.5 \%$ & $0.9 \%$ & $0.2 \%$ & $0.5 \%$ & $0.2 \%$ & \\
\hline Living & 2103 & 142 & 93 & 11 & 8 & 42 & 2399 \\
\hline$\%$ & $87.7 \%$ & $5.9 \%$ & $3.9 \%$ & $0.5 \%$ & $0.3 \%$ & $1.8 \%$ & \\
\hline
\end{tabular}

Source: NHS Blood \& Transplant, 2009

Table 4. Kidney donors in UK, Jan 04 - 2006-2008, by donor type and ethnic origin

- South Asian and African-Caribbean people wait on average twice as long as White persons for a kidney transplant. White patients wait on average 722 days, Asian patients wait 1496 days and Black people wait 1389 days (Table 5).

\begin{tabular}{|c|c|}
\hline Ethnic origin & $\begin{array}{c}\text { Average wait } \\
\text { median (days) }\end{array}$ \\
\hline White & 722 \\
\hline Asian & 1496 \\
\hline Black & 1389 \\
\hline Other & 948 \\
\hline
\end{tabular}

* based on registrations in 1998-2000

Source: NHS Blood \& Transplant, 2009

Table 5. Time actively registered on list for kidney transplant, $\mathrm{UK}^{*}$

- 1 in 8 people who died waiting for a transplant in 2006 were of African-Caribbean or South Asian origin (Table 6)

\begin{tabular}{|c|c|c|c|c|c|c|c|c|c|}
\hline $\begin{array}{c}\text { Ethnic } \\
\text { origin }\end{array}$ & Kidney & Pancreas & K/P & Heart & Lungs & H/L & Liver & TOTAL & $\%$ \\
\hline White & 212 & - & 9 & 24 & 50 & 7 & 81 & 383 & 85.5 \\
\hline Asian & 34 & - & - & 3 & - & - & 8 & 45 & $\mathbf{1 0 . 0}$ \\
\hline Black & 10 & - & - & 1 & - & - & 1 & $\mathbf{1 2}$ & 2.7 \\
\hline Chinese & 3 & - & - & - & - & - & - & 3 & $\mathbf{0 . 7}$ \\
\hline Mixed & 1 & - & - & - & - & 1 & - & $\mathbf{2}$ & $\mathbf{0 . 4}$ \\
\hline Other & 1 & - & - & 1 & - & - & 1 & 3 & $\mathbf{0 . 7}$ \\
\hline TOTAL & 261 & - & 9 & 29 & 50 & 8 & 91 & 448 & \\
\hline
\end{tabular}

Source: UK Transplant, 2007

Table 6. Patients dying in 2006 whilst list for a transplant 


\section{Improving access to services}

Research evidence has consistently demonstrated that the quality of diabetes and renal care, patient compliance, and knowledge of diabetes and its complications is lower among South Asians and African-Caribbeans (Gholap et al, 2011; Randhawa et al, 2010a; Wilkinson et al, 2011a). The UK's Department of Health has responded to this evidence by publishing a series of standard-setting documents that seek to influence public health interventions and clinical practice by highlighting the health inequalities that exist and encouraging the early identification and treatment of 'at-risk' populations. For example, The Diabetes National Service Framework (NSF) highlights the importance of improving access to services, in particular to meet the needs of minority ethnic groups (Department of Health 2002). The document also stresses the need to develop tailored education programmes to tackle issues such as diet, exercise, obesity, and treatment adherence. In a similar vein, this theme is continued within the Renal Services NSF, which also recognises the need to develop culturally-competent education programmes for the diverse renal patient population (Department of Health 2004). Within primary care, the Quality and Outcomes Framework (QOF) introduced standards for monitoring diabetes and kidney disease in 2006. These standards sought to ensure 'at-risk' patients were assessed and treated much sooner within primary care than was previously the case. A recent audit of these policy initiatives suggests that clinical practice may be improving (Wilkinson et al, 2011b).

\section{Improving transplantation rates}

A range of studies have documented that a lack of awareness concerning organ donation and transplantation among minority ethnic communities is the over-riding reason for the lack of donors from these communities. This tragically translates into higher refusal rates among non-white families (69\%) compared to white-families (35\%) in hospitals (Barber et al, 2006; Department of Health, 2008a; Perera and Mamode, 2010).

\subsection{Increasing awareness of the need for organ donors among the African-Caribbean and South Asian communities}

It is interesting to note, that once minority ethnic communities are engaged with the issue of organ donation, they are keen to lend their support and encourage their communities to sign up as organ donors (Exley et al 1996, Darr and Randhawa 1999, Hayward and Madill 2003, Alkhawari, Stimson and Warrens 2005, Davis and Randhawa, 2006, Morgan et al 2006).

Religion has also been a key influencer in the decision to donate organs or not (Randhawa et al 2010b, Hayward and Madill 2003, Alkhawari, Stimson and Warrens 2005, Davis and Randhawa 2006). Although religious interpretations are not explicit in their reference to organ donation as religious scriptures were written prior to the development of transplantation, most interpretations are broadly supportive of organ donation. However, there are some differences in opinion among some religious scholars and consequently it is imperative to support these scholars in developing an informed debate amongst their peers to reach some consensus. Subsequent to this, there is a need to identify how best to encourage religious 'stakeholders' to engage with their local community concerning the issue of organ donation and transplantation. 
In an effort to increase knowledge and awareness of organ donation among minority ethnic communities there have been a series of BME organ donor campaigns led by NHS Blood \& Transplant since 2009. These campaigns have included a series of community-based events taking place in areas of high BME-population density, supported with a range of educational materials (including religious leaflets, posters, podcasts, etc). It is too soon to comment on the success of these campaigns.

\section{Looking to the future}

It is clear that black and minority ethnic groups are disproportionately affected by renal health problems both in terms of access to appropriate services, a higher prevalence of renal complications, a reduced likelihood of a transplant, and longer waiting times on the transplant waiting list. Solutions are multi-faceted requiring a focus on the prevention of long-term conditions as well as the need to transplant patients with organ failure.

Meaningful public engagement is critical to developing tailored community education programmes that can focus both on the need to prevent and manage long-term conditions, and also focus on the need for increased organ donors from all ethnic backgrounds. This is a difficult challenge as many of these communities live within the most deprived (and hard-to-engage) communities in the UK. Not only should we engage the public with the discourse of 'disease prevention' as well as 'organ donation', but there is a need to identify whether the social class of a patient and/or their family influences live donation, as this may have implications for current reimbursement arrangements. This issue may have particular relevance to minority ethnic groups who experience the greatest levels of deprivation in the UK.

It has been suggested previously by commentators that religion acts as a prohibitor to organ donation among the South Asian population, but empirical research seems to suggest otherwise. The position of one's religion towards donation is used by individuals as a helpful guide in reaching their decision as to whether to donate or not (Randhawa et al, $2010 \mathrm{~b})$. The introduction of community-based information programmes need to be evaluated to assess whether this impacts upon the number of African-Caribbeans and South Asians on the Organ Donor Register. Indeed, all public organ donor campaigns should be formally evaluated to identify which members of the public benefit from such campaigns and to identify which members of the public are still not being reached. Moreover, research should be commissioned to identify how best to unravel public concerns that are 'cultural' as opposed to 'religious' (Randhawa et al, 2010c).

The Potential Donor Audit (an audit developed to identify the true potential for organ donation from dead donors, together with the reasons for non-donation) has highlighted the higher refusal rate for non-White potential donors compared with White potential donors (Barber et al, 2006). It is essential to ensure staff at the front line charged with approaching families for donor requests, known as Specialist Nurses for Organ Donation (SNODs), are provided with relevant training to ensure they are able to meet the needs of families from a range of ethnic and faith backgrounds.

\section{Conclusion}

Inequalities in renal and transplant services are well documented in the research literature and policymakers have sought to ensure that clinical guidance and public education 
campaigns are attuned to addressing the inequalities gap. Policy documents such as the Diabetes NSF, Renal Services NSF and QOF are heralded as landmark documents as they offer the prospect of national minimum standards for clinical care and the identification and treatment of 'at-risk' populations. The development of community-based organ donor campaigns are a recent development in the UK and have the potential to offer a more meaningful route to public engagement.

Whilst this paper has been confined to the narrow focus of ethnicity. It is worth noting that this is the case because of the availability of transplant-related data in the UK. It is likely, that similar to other areas of healthcare, that issues such as social class, gender, age, ethnicity, religion, gender, and education have a complex inter-relationship on renal health and transplantation. Therefore, it is imperative that such information is routinely collated and analysed to inform policy and practice.

\section{References}

Alkhawari, F., Stimson, G., Warrens, A. (2005) 'Attitudes towards transplantation in UK Muslim Indo-Asians in West London', American Journal of Transplantation, 5, 13261331.

Barber K, Falvey S, Hamilton C, Collett D, Rudge C. (2006) Potential for organ donation in the United Kingdom: audit of intensive care records. BMJ. 332(7550):1124-7.

Darr, A., Randhawa, G. (1999) 'Public opinion and perception of organ donation and transplantation among Asian communities: An exploratory study in Luton, UK', International Journal of Health Promotion \& Education, 37, 68-74.

Davis, C., Randhawa, G. (2006) 'The influence of religion on organ donation among the Black Caribbean and Black African population - a pilot study in the UK', Ethnicity $\mathcal{E}$ Disease, 16, 281-5.

Department of Health (2008a) Organs for Transplants: A report from the Organ Donation Taskforce. London, Department of Health, 2008, at 48.

Department of Health (2008b) The potential impact of an opt-out system for organ donation in the UK - An independent report from the Organ Donation Taskforce, London, Department of Health, 2008, at 30.

Department of Health (2004) National Service Framework for Renal Services, London: Department of Health, 2004.

Department of Health (2002) National Service Framework for Diabetes: Standards, London: Department of Health, 2002.

Exley, C., Sim, J., Reid, N., Jackson, S., West, N. (1996) 'Attitudes and beliefs within the Sikh community regarding organ donation: A pilot study', Social Science and Medicine, 43 (1996), 23-8.

Forouhi NG, Merrick D, Goyder E, et al. (2006) Diabetes prevalence in England, 2001 estimates from an epidemiological model. Diabet Med.23(2):189-197.

Gholap N, Davies M, Patel K, Sattar N, Khunti K.(2011) Type 2 diabetes and cardiovascular disease in South Asians. Prim Care Diabetes, 5(1):45-56.

Hayward, C., Madill, A. (2003) 'The meanings of organ donation: Muslims of Pakistani origin and white English nationals living in North England', Social Science $\mathcal{E}$ Medicine, 57, 389-401. 
Morgan, M., Hooper, R., Mayblin, M., Jones, R. (2006) 'Attitudes to kidney donation and registering as a donor among ethnic groups in the UK', Journal of Public Health, 28, 226-234.

Parera S and Mamode N (2010) South Asian patients awaiting organ transplantation in the UK. Nephrology Dialysis and Transplantation, 26, 1380-4.

Randhawa G, Jetha C, Gill B, Paramasivan S, Lightstone E, Waqar M (2010a) Understanding kidney disease and perceptions of kidney services among South Asians in West London: focus group study. British Journal of Renal Medicine. 15, 23-28.

Randhawa G, Brocklehurst A, Pateman R, Kinsella S, Parry V (2010b) ‘Opting-in or Optingout?' The views of the UK's Faith leaders in relation to organ donation. Journal of Health Policy. 96, 36-44.

Randhawa G, Brocklehurst A, Pateman R, Kinsella S, Parry V (2010c) Utilising faith communities in the UK to promote the organ donation debate: The views of UK faith leaders. Journal of Diversity in Health and Social Care, 7, 57-64.

Randhawa, G. (1997) 'Enhancing the health professional's role in requesting transplant organs', British Journal of Nursing, 6, 429-434.

Randhawa, G. (1998) 'The impending kidney transplant crisis for the Asian population in the UK', Public Health,112, 265-8.

Riste L, Khan F, Cruickshank K.(2001) High prevalence of type 2 diabetes in all ethnic groups, including Europeans, in a British inner city: relative poverty, history, inactivity, or 21st century Europe? Diabetes Care.24(8):1377-1383.

Roderick P, Hollinshead J, O'Donoghue D, Matthews B, Beard C, Parker S, Snook M (2011) Health inequalities and chronic kidney disease in adults. London, NHS Kidney Care.

Roderick, P., Raleigh, V., Hallam, L., Mallick, N. (1996) 'The need and demand for renal replacement therapy amongst ethnic minorities in England', Journal of Epidemiology and Community Health, 50, 334-9.

Wilkinson, E., Randhawa, G., Farrington, K., Feehally, J., Choi, P., Lightstone, L. (2011a) Lack of awareness of kidney complications despite familiarity with diabetes - a multi-ethnic qualitative study. Journal of Renal Care, 37, 2-11.

Wilkinson E, Randhawa, G, Roderick P, Rehman T, Abubacker T (2011b) The impact of quality improvement initiatives on diabetes care among South Asian people. Diabetes \& Primary Care, 13, 90-98. 


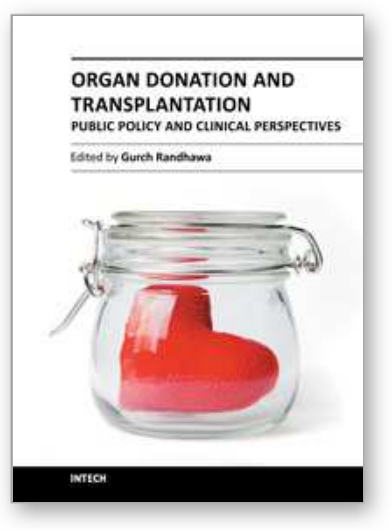

\author{
Organ Donation and Transplantation - Public Policy and Clinical \\ Perspectives \\ Edited by Dr. Gurch Randhawa
}

ISBN 978-953-51-0039-3

Hard cover, 284 pages

Publisher InTech

Published online 08, February, 2012

Published in print edition February, 2012

Transplantation has succeeded in prolonging the lives of those fortunate enough to have received the gift of a body organ. Alongside this life-saving development, there lies another sadder side to the story - there are not enough organs to meet the ever increasing demand. This not only places an increasing emotional and physical burden among the waiting patients and families but heaps a great financial burden upon health services. This book provides an analysis and overview of public policy developments and clinical developments that will hopefully ensure an increased availability of organs and greater graft survival. Medical, policy, and academic experts from around the world have contributed chapters to the book.

\title{
How to reference
}

In order to correctly reference this scholarly work, feel free to copy and paste the following:

Gurch Randhawa (2012). Transplant Inequalities - A United Kingdom Perspective, Organ Donation and Transplantation - Public Policy and Clinical Perspectives, Dr. Gurch Randhawa (Ed.), ISBN: 978-953-51-00393, InTech, Available from: http://www.intechopen.com/books/organ-donation-and-transplantation-public-policyand-clinical-perspectives/transplant-inequalities-a-united-kingdom-perspective

\section{INTECH}

open science | open minds

\section{InTech Europe}

University Campus STeP Ri Slavka Krautzeka 83/A 51000 Rijeka, Croatia Phone: +385 (51) 770447

Fax: +385 (51) 686166 www.intechopen.com

\section{InTech China}

Unit 405, Office Block, Hotel Equatorial Shanghai No.65, Yan An Road (West), Shanghai, 200040, China 中国上海市延安西路65号上海国际贵都大饭店办公楼405单元 Phone: +86-21-62489820

Fax: +86-21-62489821 